\title{
The European Semester Process: Adaptability and Latitude in Support of the European Social Model
}

\author{
Sonja Bekker
}

\subsection{INTRODUCTION}

The establishment of the European Semester and its stricter economic governance has sparked off many debates, also addressing the impact on the European Social Model (ESM). Research has focused mainly on mapping out the new EU regulatory framework, or on assessing national-level structural reforms. Much less attention has been given to the exchange between the EU Institutions and the Member States, within the so-called 'throughput' phase of policy-making. This chapter gives more insight into this interaction by answering the question of to what degree the European Semester adapts its goals to new challenges and what leeway Member States have to implement alternative policies. The degree of adaptability and latitude indicate the perspective of social goals within the European Semester. The chapter scrutinises EU socioeconomic governance between 2009 and 2015. It looks at the changes in EU-level goals and the responses of France, Germany, Poland, and Spain in three key dossiers: unemployment, wage-setting, and pension schemes. The conclusion is that the European Semester adapts its goals. It tailors recommendations to specific national challenges and changes its focus from time to time. This goes to show that the European Semester is not a static but an evolving governance structure. Moreover, Member States have latitude to deal with EU demands in different ways. All four Member States question some of the Commission's evaluations and recommendations. They propose alternative views on sound socioeconomic policies and may even implement policies that go against the EU recommendations. They do so based on a range of arguments, including that of safeguarding social policies. Both the adaptability of the European Semester and the leeway of Member States are important ingredients of the governance process. It offers scope for learning and evolution and thereby provides opportunities for strengthening the ESM. 


\subsection{THE EUROPEAN SEMESTER AND ITS SOFT-LAW ROOTS}

The European Semester has been introduced after the start of the crisis. One of its purposes was to make Member States comply better with fiscal rules and to avoid macroeconomic imbalances that could spill over to other countries. The Semester integrates a range of socioeconomic coordination mechanisms, including the Europe 2020 Strategy, the Macroeconomic Imbalances Procedure (MIP) and the Stability and Growth Pact (SGP). The Six-Pack (2011) and the Fiscal Compact (2013) strengthened the already existing SGP and introduced the MIP for the early detection of national macroeconomic imbalances. Both these fiscal and economic coordination cycles have a preventative but also corrective arm that may result in financial penalties for euro area countries. The Europe 2020 Strategy has remained a soft coordination cycle and mostly addresses employment and social policies, including the integrated guidelines for economic and employment policies. Europe 2020 hosts ambitious goals such as reducing the number of people who experience poverty, thereby supporting the ESM. However, during the first years of the economic crisis the EU's focus was on reducing national public expenditure. There was much less consideration for social goals. The fiscal focus coincided with numerous accounts of austerity measures and structural reforms at the national level, which often harmed social policy initiatives. ${ }^{1}$ However, in spite of this correlation between stricter EU fiscal rules and national reforms, questions remain on the nature and magnitude of a causal link between the $\mathrm{EU}$ rules and the national outcomes. These questions are inspired by the pre-crisis literature on soft governance of employment and social policies via the Open Method of Coordination (OMC) and the limited competences the EU has to mingle into national social domains. ${ }^{2}$ Such questions are furthered by more recent literature pointing at the importance of the throughput phase of policy-making. ${ }^{3}$ This throughput phase ties the input of a decision-making (for instance the rules) process to its output (for instance domestic policy changes).

E. Achtsioglou and M. Doherty, "There Must Be Some Way Out of Here ... The Crisis, Labour Rights and Member States in the Eye of the Storm' (2014) 20 European Law Journal 219; C. Degryse, M. Jepsen, and P. Pochet, "The Euro Crisis and Its Impact on National and European Social Policies' (2013) European Trade Union Institute (ETUI) Working Paper, 05; and J. López and S. Canalda Criado, 'Breaking the Equilibrium between Flexibility and Security: Flexiprecarity as the Spanish Version of the Model' (2014) 5 European Labour Law Journal 22.

$=$ J.Zeitlin, P. Pochet, and L. Magnussen (eds), The Open Method of Coordination in Action: The European Employment and Social Inclusions Strategies (P.I.E.-Peter Lang, 2005).

3 V. Schmidt, 'Democracy and Legitimacy in the European Union Revisited: Input, Output and "throughput" (2013) 61 Political Studies 2. 
From a legal perspective, Member States have much autonomy to develop social policies according to their own needs. Soft coordination gives the EU a means to set common goals, yet also acknowledges that Member States have different ways to reach these goals. This soft coordination is still the basis of the Europe 2020 Strategy. The pre-crisis literature argues that a choice for soft coordination is not necessarily 'second-best' in absence of 'hard' competences. Benefits of soft coordination over top-down and uniform rules have been documented well. Leaving policy design and implementation to the national level makes it easier to take a complex set of factors and institutions into account when developing policies. ${ }^{4}$ Soft coordination also offers higher degrees of flexibility, the participation of actors in various stages of policy or law formation, and moreover makes it possible to adapt targets to new challenges. 5 The $\mathrm{OMC}$ also initiates an iterative process of mutual learning, stimulating actors to meet and reflect on policies and its purposes. ${ }^{6}$ Within the setting of the EU, this would imply that an exchange between the EU-level institutions and the Member States takes place. The European Semester increasingly offers such moments to exchange views. Its 2015 version includes for instance bilateral meetings between the EU and the Member States. During such meetings, the whole range of socioeconomic realities, targets and priorities might be discussed and weighed against each other. This could offer opportunities to argue for a social agenda. Such exchanges happen in the throughput stage of policy-making, and co-determine policy-making outcomes. 7 The throughput stage is however relatively unexplored, especially in the context of the European Semester. This chapter offers a first exploration by assessing the adaptability of the European Semester and the latitude of Member States to discard $\mathrm{EU}$ demands or to bring alternative ideas into the process. If the European Semester can adapt its goals, this might give space for social goals to anchor deeper into the process. Likewise, if Member States have leeway to develop alternative policies, then a stronger social dimension may be built into national socioeconomic policies.

4 J. Lenoble, 'Open Method of Coordination and Theory of Reflexive Governance', in O. De Schutter and S. Deakin (eds), Social Rights and Market Forces: Is the Open Coordination of Employment and Social Policies the Future of Social Europe? (Bruylant, 2005); J. Scott and D.M. Trubek, 'Mind the Gap: Law and New Approaches to New Governance in the European Union' (2002) 8 European Law Journal 1.

5 B. Eberlein and D. Kerwer, 'New Governance in the European Union: A Theoretical Perspective' (2004) 42 Journal of Common Market Studies 121; and J.S. Mosher and D.M. Trubek, 'Alternative Approaches to Governance in the EU: EU Social Policy and the European Employment Strategy' (2003) 41 Journal of Common Market Studies 63.

6 Eberlein and Kerwer, n. 5 in this chapter.

7 Schmidt, n. 3 in this chapter. 


\subsection{THE EUROPEAN SEMESTER AS A HYBRID GOVERNANCE} STRUCTURE

The introduction of stricter economic governance to improve Member State compliance with EU fiscal targets suggests a limited space for Member States to develop socioeconomic policies. It is challenging to typify coordination within the European Semester, as it yokes together different instruments and coordination mechanisms within one time-frame, using structures that resemble intergovernmentalism as well as the Community Method. ${ }^{8}$ Several characteristics would justify seeing the Semester as a hybrid governance process. Hybrid governance structures contain both hard and soft processes within the same domain and these affect the same actors. ${ }^{9}$ A first indication of its hybrid character is the Semester's combination of the coercive SGP and MIP surveillance with the soft Europe 2020 Strategy coordination. A second indication is the hybrid character of two of the Semester's coordination mechanisms: the SGP and the MIP. They both have a rather soft, preventative arm and a hard, corrective arm. The Excessive Deficit Procedure (EDP) is the corrective arm of the SGP and the Excessive Imbalance Procedure (EIP) is the MIP's corrective arm.

In operation, the hybrid character of the Semester gains complexity. Firstly, only euro area countries that perpetually fail to meet fiscal rules (SGP), or keep having severe macroeconomic imbalances (MIP), may eventually get a sanction. It means that for some countries surveillance is much stricter than for others. Still, it is hard to determine when exactly a penalty is given. Practice shows that deadline postponements for meeting fiscal rules occur frequently. A recent Communication explains which flexibility the SGP rules have. ${ }^{10}$ During the 2016 European Semester, speculations were made on stepping up the EDP for Spain and Portugal. The Commission argued, however, that it was economically and politically not the right moment to do so. It decided to give the two countries an additional year to bring deficits down, while demanding strong and rapid reform efforts. ${ }^{11}$ Thus, being in the corrective stage of the SGP might not necessarily lead to punitive actions rapidly.

8 K.A. Armstrong, 'The New Governance of EU Fiscal Discipline' (2013) $3^{8}$ European Law Review 6o1; and M. Dawson, "The Legal and Political Accountability Structure of "Post-Crisis" EU Economic Governance' (2015) 53 Journal of Common Market Studies 976.

9 D.M. Trubek, P. Cottrell, and M. Nance " "Soft Law," "Hard Law," and European Integration: Towards a Theory of Hybridity' (2005) University of Wisconsin Legal Studies Research Paper, 1002.

1. $\mathrm{COM}(2015)$ o12 Making the Best Use of the Flexibility within the Existing Rules of the Stability and Growth Pact (Brussels, 14 January 2015).

${ }^{11}$ P. Moscovici, Live Read-out of the College Meeting of 18/05/2016 (Ref: I-121291, 18 May 2016). 
Actually, the toughest surveillance is placed upon Member States that fall outside the scope of the European Semester: the bailout or programme countries. These countries have received financial assistance packages on the condition of, among others, drastic cuts in social expenditure and major structural reforms. This has harmed the social state of these countries considerably, leaving them little room to invest in citizens and society. ${ }^{12}$ In 2016 , only Greece was in such a macroeconomic adjustment programme, while in 2015 both Greece and Cyprus were in an adjustment programme. The largest group of countries thus falls within the scope of ordinary surveillance via the European Semester. Secondly, in its everyday operation the three distinct coordination mechanisms of the European Semester influence each other. ${ }^{13}$ Thus, in spite of the fact that the coordination mechanisms have their own legal basis, mutual influence occurs. It is caused by the separate coordination mechanisms evaluating the same policies. ${ }^{14}$ For example, the pension system is interesting to evaluate from a social policy perspective, yet also co-determines the government's fiscal situation. It has therefore been an element in the SGP, the MIP as well as Europe 2020. ${ }^{5}$ Especially the Country Specific Recommendations (CSRs) demonstrate the coordination mechanisms' interest in similar policies. CSRs are the outcome of the European Semester and advise each Member State which policies to implement. From 2011 onwards, the CSRs of the three coordination mechanisms have been placed together into one list of recommendations. Especially the MIP frequently assesses items that also belong to soft employment and social policy coordination domains, including topics such as unemployment, minimum wages, and the labour-market integration of vulnerable groups. This mutual influence could result in a stronger coordination of social policies. ${ }^{16}$ Indeed, new EU economic coordination may inhibit quite fundamental choices for roads to political integration. ${ }^{17}$ At the same time it has important limitations such as weak accountability for central prescription and control of economic and fiscal policies and a significant differentiation of

${ }_{12}$ Achtsioglou and Doherty, n. 1 in this chapter; F. Costamagna, 'Saving Europe "Under Strict Conditionality”: A Threat for EU Social Dimension?' (2012) LPF Working Paper, 7; and C. Kilpatrick and B. De Witte, 'A Comparative Framing of Fundamental Rights Challenges to Social Crisis Measures in the Eurozone' (2014) 7 SIEPS European Policy Analysis 1.

13 Armstrong, n. 8 in this chapter.

14 S. Bekker, "EU Coordination of Welfare States after the Crisis: Further Interconnecting Soft and Hard Law' (2014) 19 International Review of Public Administration 296.

15 S. Bekker, 'European Socioeconomic Governance in Action: Coordinating Social Policies in the Third European Semester' (2015) OSE Research Paper Series, 19.

16 Bekker, n. 14 in this chapter.

${ }^{17}$ A. Hinarejos, 'Fiscal Federalism in the European Union: Evolution and Future Choices for EMU' (2013) 50 Common Market Law Review 1621. 
obligations between states. ${ }^{18}$ These fundamental choices for roads to political integration, as well as the system's limitations, intensify if budgetary coordination starts dealing with social policies. At the same time, there is little insight into the causal mechanisms, linking the setup of the Semester to implications for national reforms. Moreover, the fact that the MIP and SGP address social policies does not reveal whether their recommendations support or harm the obtainment of social goals. Both the SGP and the MIP are capable of supporting social goals. ${ }^{19}$

\subsubsection{Analytical Framework}

One opportunity to strengthen the ESM emerges when the European Semester is able to adapt its goals to new social challenges. Another opportunity is national latitude to develop socioeconomic policies. This section proposes the following analytical framework to measure the degree of adaptability and leeway. Features of adaptability at the EU level include:

- general EU-level targets change from year to year;

- changes in the 'strictness' of coordination, exploring whether countries move from preventative to corrective stages, or from corrective to preventative stages;

- emergence or disappearance of new topics in CSRs.

The analysis combines these indicators with assessing whether the Semester gives tailor-made advice to countries, adjusted to national challenges. Another important indicator is whether or not the Commission's recommendations are precise or vague. Vagueness allows for further specification at national level, thus providing scope for giving reforms a national flavour. Getting imprecise CSRs is especially relevant once countries proceed into the corrective arm of surveillance, where pressure to comply is expected to be higher. The following indicators suggest latitude of Member States to hold conflicting opinions or to develop alternative policies:

- presenting alternative policies to meet the challenges addressed by a CSR, or to meet the EU's overall socioeconomic goals;

- implementing policies that go against a CSR;

- perpetual noncompliance with CSRs, thus discarding EU policy advice.

18 Dawson, n. 8 in this chapter.

19 Bekker, n. 15 in this chapter; J. Zeitlin and B. Vanhercke, Socializing the European Semester? Economic Governance and Social Policy Coordination in Europe 2020 (SIEPS, 2014). 
- disagreeing with EU calculation methods to measure policy outcomes or the socioeconomic state of a country;

- presenting alternative ideas or philosophies about sound socioeconomic policies.

These indicators are quite relevant to assess the space for bottom-up initiatives and ideas to emerge into the coordination process.

The analysis takes a longitudinal approach, covering the years 2009 to 2015. It captures trends in the Semester's goals and priorities, as well as including the national reforms and subsequent EU-level reaction. The time period covers the last coordination cycle of the Lisbon Strategy and the five subsequent European Semester policy cycles. The analysis includes the EU on the one hand, and the reactions of France, Germany, Poland, and Spain on the other hand, and specifically looks at the topics of pensions, wages, and unemployment. The assumption is that the four countries experience different degrees of pressure to comply with EU target, while also experiencing different degrees of freedom to develop alternative policies. Germany and Poland are likely to feel the lowest pressure to comply. Germany has mostly been in preventative coordination stages, having left the EDP in 2012. Poland has been in the EDP until 2015, however, does not belong to the euro area and therefore cannot get fines. Still, as Poland has the ambition to join the Euro, it could feel the need to meet fiscal targets nevertheless. The assumption is also that Spain and France perceive the highest pressure to comply with EU demands. Both countries have been in EDP in all years scrutinised. Spain moreover signed for a loan to support its financial sector, likely resulting in additional pressure to comply. ${ }^{20}$ Furthermore, as of 2012 Spain and France have been part of an In-Depth Review (IDR), the second stage of the MIP. Germany was subject to an IDR only as of 2014, while Poland has never been suspected of having macroeconomic imbalances. Data sources include all European Semester documents that are relevant for the four countries in the years scrutinised: National Reform Programmes (NRPs) and Stability or Convergence Programmes of national governments and the CSRs and Country Reports (formerly divided into separate staff working papers and IDRs) of the EU. In total over 43 national-level and more than 44 EU-level documents have been explored, using a qualitative content analysis technique. ${ }^{21}$

${ }^{20}$ Kilpatrick and De Witte, n. 12 in this chapter.

${ }^{21}$ A full overview of the findings, including an extensive reference list is available in S. Bekker, 'Is There Flexibility in the European Semester Process? Exploring Interactions between the EU and Member States within Post-crisis Socio-economic Governance' (2016) 1 SIEPS report 1. 


\subsection{THE EUROPEAN SEMESTER: ADAPTING ITS GOALS TO NEW PRIORITIES AND COUNTRY-SPECIFIC CHALLENGES}

Before introducing stricter economic governance, the European Commission's initial crisis response was to stimulate the economy by asking Member States to increase public expenditure. This policy was codified in the European Economic Recovery Plan in 2009. Only after 2009, meeting debt and deficit rules were prioritised. Thus, the initial response of increasing public expenditure was changed into active policies to reduce public expenditure. However, as time progressed, the concern for social policies emerged, largely resulting from worries about (youth) unemployment rates, growing poverty, and rising inequality. ${ }^{22}$ After 2012, such concerns became part of the Annual Growth Survey, which started addressing unemployment and the social consequences of the crisis, and later on also investments. The Commission moreover launched an Employment Package (2012), a Social Investment Package (2013) and a Youth Guarantee (2013). Furthermore, as of 2014 the Joint Employment Report has incorporated a scoreboard of key employment and social indicators. This demonstrates that the $\mathrm{EU}$ is able adapts its primary goals to new challenges. It has offered social goals a chance to integrate better within the overall set of EU socioeconomic goals. The CSRs show a likewise adaptability. They vary from year to year. This change does not necessarily relate to national compliance and policy implementation, as the following sections will demonstrate. One major change relates to the instalment of the Juncker Commission that wanted to focus the CSRs on priorities. It led to a large reduction in the number of CSRs in 2015, and moreover made CSRs less precise. Current CSRs include less often very specific policies that should be amended before a given deadline. ${ }^{23}$ The European Semester also demonstrates adaptability in the changing strictness of coordination. Sometimes, countries have moved from corrective into preventative coordination stages. For instance, the French pension system has been explored often from the SGP, yet this ceased to be the case in 2015. Moreover, as was the case before the crisis, CSRs are still tailored to the challenges of a specific country. They thus do not necessarily have a uniform approach to all countries. Still, social policies are more frequently explored from economic coordination mechanisms. In particular the MIP evaluates an increasing amount of social policy areas. Both in 2013 and 2015 about half of the CSRs addressed at least one social policy item. However, whereas in 2013 about

22 $\mathrm{COM}(2013) 083$ towards Social Investment for Growth and Cohesion - Including Implementing the European Social Fund 2014-2020 (Brussels, 20 February 2013).

23 See also Bekker, n. 14 in this chapter. 
50 per cent of the social policy CSRs were attached to the MIP and/or SGP in 2015 this has risen to around 70 per cent.

Thus, while EU socioeconomic coordination might be judged as stricter governance, there are also signs of adaptability and quite loose enforcement, including frequent postponement of deadlines for meeting fiscal rules. Although the SGP and MIP evaluate social policies as well, it is too early to judge whether this means tighter coordination of social policies. Recent ideas presented by the Five Presidents' Report and the subsequent Communication on completing the Economic and Monetary Union, ${ }^{24}$ do not give conclusive answers. On the one hand, the Commission wants to toughen surveillance further. For example, the national budgetary policies should be consistent with the SGP recommendations and, where appropriate, with the MIP recommendation. Also the European Social Funds (ESF) are tied to implementing the CSRs. National ESF-programmes should have objectives, financial allocations, and investment priorities that contribute to Europe 2020 goals, the challenges in the NRP, and the CSRs. Failure may result in fines and/or suspension of up to five European Funds. On the other hand, the Commission says to value the diversity among Member States and mentions that Member States should not necessarily follow the same policies. Only the outcome matters. The Commission also wants more focus on employment and social performance: a Social Triple A. These different thoughts on future governance do not articulate how distinct coordination mechanisms should relate to each other or how much room Member States should have to develop sound social policies. The next sections zoom in on the three selected policy areas and further explores the adaptability of the European Semester.

\subsubsection{Unemployment}

The topic 'unemployment' demonstrates the different focus per country and per year, as well as the Semester's ability to show a social face. In the Commission's evaluation of France, unemployment has not been a very pressing issue. In 2009, unemployment is only mentioned in a CSR addressing the support of labour-market entry and transitions, especially of young people. Two years later, the Council concluded that France's economic stabilisers, although being costly, had lowered the impact of the economic crisis considerably. In 2013, unemployment was still not seen as the most urgent matter for France, but related recommendations were expanded nevertheless. Such

$24 \operatorname{COM}(2015) 0600$ Steps Towards Completing Economic and Monetary Union (Brussels, 21 November 2015). 
expansion was in line with the growing precision of CSRs in those years. It moreover correlated with new regulations requiring the Commission to draft more specific recommendations if a country progresses into corrective surveillance. In 2013 and 2014, France's unemployment recommendations were tied to the IDR. In 2015, after refocusing all CSRs to priorities only, unemployment was no longer specifically addressed, in spite of remaining challenges. The Country report 2015 on France even saw an increase in unemployment, particularly among young people, older workers, and the low-qualified.

Also for Germany, unemployment has not been a key issue in EU socioeconomic coordination. Aspects of the quality of employment have been addressed frequently, however. It underlines the Semester's ability support social goals. The Commission pointed continuously at the low quality of German mini-jobs, including their low pension entitlements and low transition prospects into stable jobs. ${ }^{25}$ The Commission's background documents perpetually addressed the inequality related to mini-jobs, but did not translate it into CSRs every year. For instance, despite remaining challenges, it was absent in the $2014 \mathrm{CSR}$. It reappeared in the 2015 CSRs calling Germany to revise the fiscal treatment of mini-jobs in order to facilitate the transition into other jobs. Similarly, for Poland unemployment was not really an issue, yet the quality of jobs was. After 2012 the high youth unemployment became a concern, including the effects of labour-market segmentation. The Commission analysed that temporary contracts insufficiently act as a stepping-stone into regular employment, include a large wage penalty, and have a negative impact on human capital and productivity in Poland. This issue was taken up more vigorously in 2012 and 2013; however, the Commission did not really observe progress in the subsequent years. It included the issue of the excessive use of temporary contracts again in the 2015 CSRs. In the analyses of the Spanish labour-market unemployment has been highly relevant. In 2011, the Commission worried because Spain was severely hit by the crisis, yet also expected unemployment to decrease after 2012. This expectation was not met and by 2013 the word 'critical' was used to describe the Spanish labour market. In 2014 youth unemployment remained high and longterm unemployment grew to almost 50 per cent. Accordingly, between 2009 and 2015 the CSRs addressed unemployment, including references to reducing labour-market segmentation, tackling youth unemployment, modernising public employment services, and improving training and job-matching. On the one hand such concerns easily match with social issues. On the other hand, the large labour-market reforms that Spain implemented in the past years have

25 S. Bekker and S. Klosse, "EU Governance of Economic and Social Policies: Chances and Challenges for Social Europe' (2013) 2 European Journal of Social Law 103. 
been judged as undermining social fairness. ${ }^{26}$ Reforms included sensitive dossiers such as employment protection legislation and the collective bargaining system. Overall, the Commission was positive about the Spanish reforms, even though it kept underlining that the magnitude of the necessary corrections require continuous and strong policy measures. In 2016 this was followed by the speculations mentioned in Section 11.3, about sanctions and increased pressure to continue reforming.

\subsubsection{Wages}

Also regarding wages, the European Semester shows adaptability as well as the tailored policy-advice to countries. For France wages were not addressed in 2009, yet, after 2011 it gradually turned into a main issue. The Commission related wages to the competitiveness of France and tied it to the IDR after 2012. The attention for wages culminated in long and rather precise CSRs in 2013 and 2014. Even the 2015 CSRs paid much attention to reducing labour costs, reforming the wage-setting process to align wages with productivity, and minimum wages. The Commission thus kept addressing a range of wage-related issues, especially from an economic perspective. The 2015 CSR remained quite precise, in spite of the Commission's aim to focus on priorities. The Commission observed noncompliance with CSRs on wages, and even a reform going against a CSR. In 2012, France increased the minimum wage slightly, regardless of requests to view the minimum wage in line with job creation and competitiveness. France thus saw space to develop alternative policies, even though the CSR on minimum wages was tied to the IDR of the MIP. In 2014, the Commission's evaluation was somewhat milder. This evaluation sustained in 2015 , seeing significant progress in dossiers such as the tax credit for competitiveness and employment, which reduce labour costs. Conversely, the Commission judged that only limited progress was made in reducing the cost of labour at the lower end of the wage scale. Also in the surveillance of Germany, wages have been addressed frequently. As of 2011, the high tax wedges have been a relevant issue. In 2012 this was related to the unemployment of low-wage earners, and further defined into reducing high taxes and social security contributions for this group in 2013 and 2014. The purpose of the reform was giving low-wage earners better job prospects. From 2012 onwards the Commission started suggesting to increase wages by letting these grow in line with productivity and to support domestic demand. ${ }^{27}$ All

26 López and Canalda Criado, n. 1 in this chapter.

${ }_{27}$ See also Bekker and Klosse, n. 25 in this chapter. 
these issues have been addressed via soft coordination. In 2014 a third topic was added, and this issue was attached to the IDR: the minimum wage. It resulted from Germany's announcement to introduce a national minimum wage. The CSR requested Germany to monitor the impact of the minimum wage on employment, so as to avoid job destruction. In the surveillance of Poland, wages have not been a great concern. CSRs at times referred to inwork-poverty, suggesting that wage levels are too low rather than too high. Thus, also poverty reduction may be part of European Semester coordination, thus supporting social goals. In 2012, in-work-poverty was linked to youth unemployment and the segmented labour market. It addressed the partial abuse of self-employment and civil law contracts that fall beyond the scope of Labour Law. For temporary workers in Poland, in-work poverty is twice as high as for workers on permanent contracts, also due to wage penalties related to flex work. Moreover, due to a low statutory minimum wage, low net transfers to low-income earners and stringent eligibility rules, people tend to be trapped in poorly paid jobs. In 2013 , continuing worries on this issue were translated into a CSR again; however, the 2014 CSRs no longer addressed in-work-poverty. It kept being part of the concerns expressed in the Commission's Country reports. Only labour-market segmentation remained part of the CSRs in 2014 and 2015 .

In the surveillance of Spain, wages have continuously been addressed in the background documents, yet did not always result in a CSR. In 2009, the Commission observed that Spanish wage developments should be aligned better with productivity developments, in order to improve competitiveness. No CSR was issued then. In 2011 this changed. The CSRs called to proceed with the implementation of a comprehensive reform of the collective bargaining process and the wage indexation system. Perhaps due to the reform efforts along the line of the CSRs, the 2012 and 2013 CSRs no longer mentioned wages. However, it became part of the 2014 CSRs again, albeit in a completely different manner. The suggestion was to lower employer's social security contributions, in particular for low-wage jobs, and to promote real wage developments that support job creation. The part on social security contribution was even attached to both the SGP and the IDR, whereas the issue of real wage development was tied to the IDR. In the 2015 CSRs, the wage issue changed again into addressing the alignment of wages and productivity. This Spanish monitoring cycle indicates that the Commission may stop giving CSRs on a certain topic if reforms have been implemented. This does not mean that topics disappear from the monitoring cycle completely, however. Issues may recur when new challenges arise. This demonstrates a certain degree of adaptability of the coordination process. 


\subsubsection{Pension System}

Also regarding pensions, coordination adapted itself to the country and its challenges. France received a CSR on pensions in all years. Between 2011 and 2014 this was tied to the SGP and in addition linked to the IDR between 2013 and 2015. The pension CSRs to France also became much more detailed after 2013 , including a very precise description of how to reform pensions. At first, the Council ${ }^{28}$ seemed satisfied with the French pension reform of 2010 , which increased the pension age to 67 , set a higher minimum pension age (from 60 to 62 ) and phased out early retirement schemes. However, in the same year the Council predicted that more measures would be needed, especially due to high public debt. In 2012, a similar CSR was given, adding the need to review the adequacy of the pension system in addition to its sustainability. The language of the 2013 CSR was much firmer, stating that France should take new measures to bring the pension system into balance by 2020 , and giving a precise list of examples of how France could do this. This firm language related to the partial rollback of the 2010 pension reforms, which explicitly went against the 2012 CSR. This rollback was installed by a newly elected French government. This again shows that France found opportunities to implement reforms that countered CSRs. In December 2013 France implemented another pension reform, and the Commission valued this reform to some extent. It was followed by a somewhat milder CSR which was no longer tied to the SGP in 2015. For Germany, the topic of pensions was only converted into a CSR in 2014. However, it was addressed in the Commission's background analyses for longer. Worries concerned the low employment rate of older workers and the low attainment of pension rights for people in a mini-job. It moreover saw lower pension contributions as a partial answer to decrease wage-related taxes. This minor interest in the German pension system changed in 2014, when the topic was suddenly explored from both the SGP and the IDR. This had to do with the German pension reform that aimed at improving early retirement conditions as well as increasing pension levels for certain groups, for instance for people who raised children born before 1992. The Council found that the reform was at odds with the cost-effectiveness of public spending and the development of disposable income, worrying also about the potentially negative effects on the take-up of the second and third pillar pensions. The 2015 CSRs no longer addressed pensions, signalling that it no longer belonged to

28 Council Recommendation (2011/C 213/03) of 12 July 2011 on the National Reform Programme 2011 of France and delivering a Council opinion on the updated Stability Programme of France, 2011-14, [2011] OJ C 213/8. 
the Commission's priorities. In the surveillance of Poland, the pension system was an item in all years, especially the KRUS pension provisions for farmers. The Commission observed only minor changes in the Polish system. In the assessments of Spain, pensions were hardly at the core of evaluations.

\subsection{NATIONAL RESPONSES TO EU-LEVEL SOCIOECONOMIC TARGETS}

The annual national reports give insight into the reasoning of Member States in coordination processes and the reform choices they make. In spite of the fact that all four countries underline their commitment to reaching the EU-level goals, the national documents reveal disagreement as well. There are conflicting views on what sound socioeconomic policy entail, different insights in calculation methods of deficits and reform effects, and some issues concerning legitimacy. Moreover, Member States find that they cannot influence all aspects of globalised economies. Indeed, their policy instruments are more limited than the European Semester's surveillance logic supposes. Whereas all of these arguments are to some extent interconnected, the following subsections present them separately.

\subsubsection{Ideas on the Nature of Sound Socioeconomic Policies}

The 2012 NRP reveals France's reform philosophy: to combine fiscal consolidation with high growth potential in order to revive economic growth and support the labour market. This also means limiting the negative social consequences of the crisis and promoting social cohesion. In support of its reform philosophy, it referred to the Commission's social goals, such as the Compact for Growth and Jobs (2013) and the European Youth Employment Initiative. Germany communicated a similar philosophy in many NRPs. It is a social market economy, giving equal importance to economy and competition as to equal opportunities and social inclusion. At times, such philosophies explain reform choices of the two countries. For example, whereas the 2014 CSRs worried about the German pension reforms from a budgetary viewpoint, Germany explained these reforms as a means to reach the EU target on social inclusion and poverty reduction. Germany wanted to prevent old-age poverty and therefore improved the pensions of people with a reduced earning capacity.

The consecutive Polish NRPs show increasing awareness of the effects of cuts in public expenditure as well as the difficulties to predict the effects of reforms for public budgets. Around 2009, the Polish government expressed readiness to reduce the fiscal imbalance, and even found that its imbalances were a result of past neglect to restructure. It prepared a reform package, 
whilst searching for some balance between investing in growth and consolidating public finances. The NRP 2009 further explained this as an aim to create a basis for long-lasting socioeconomic development which should also result in better living standards. Such aims remained an item in subsequent Polish national reports. In 2011, Poland defended some form of public expenditure by explaining that investments in social infrastructure (for example education, health care, culture) are a way to unleash regional potential and contribute to social inclusion. In 2013 and 2014 the country highlighted again the importance of a growth-friendly fiscal consolidation. It no longer saw further cuts in public expenditure as the sole remedy for economic misery. Poland clarified that bringing deficits below 3 per cent was difficult, despite restructuring efforts. Although the Commission gave a positive evaluation of Poland's reform plans, these efforts did not generate the expected budgetary goals. Even reform plans that were predicted to exceed the deficit reduction target, did not generate the expected results. In 2014 Poland explained this by pointing at the negative impact of fiscal consolidation on economic growth. It challenged the EU recommendations, arguing that a further reduction of the deficit would be strongly pro-cyclical and consequently affect economic growth prospects. This would reduce tax revenues, and subsequently increase the government deficit. Despite this plea for investing in growth, Poland presented further measures to limit deficit growth.

\subsubsection{Conflicting Views on Calculation Methods and Reform Effects}

The Polish example in Section 11.5.1 shows how different ideas on sound socioeconomic policies are tied to disputes on how to forecast future deficits. If cutting public expenditure does not have the desired effect, then investing in growth perhaps would. In their national reports all four Member States disagreed with the Commission's calculations from time to time. Whereas such disputes may address minor details, these details become quite important if resulting in negative evaluations.

Germany's account surplus was a topic of analysis. On the causes of this account surplus, Germany both agreed and disagreed with the Commission. It underlined the Commission's analysis that price competition plays a minor role in the expansion of the trade balance. The federal government also shared the view that the increase in consumer spending was below the Eurozone average, and that this partly resulted from the moderate wage development of the past 14 years. However, the country disputed that it should implement policies to increase wages. It referred to a study of the Commission which concluded that wage moderation only marginally affects account surpluses. 
Moreover, Germany found past wage moderation necessary, in light of the high unemployment rates, the weak economy and the poor profitability conditions of businesses. Furthermore, Germany gave an alternative reason for the low consumer spending: the high savings related to the ageing society and the pension system. The country thus found that the Commission did not take all relevant elements into account when calculating and explaining the account surplus. Still it made further plans to stimulate internal growth. This included the introduction of a legal minimum wage and investments in childcare facilities which should support female labour-market integration. The Commission was not overly enthusiastic about this minimum wage and feared negative effects on employment, however. Germany believed that further government intervention was not necessary, as the good economy would automatically result in more jobs and higher wages. This would then raise household income and subsequently increase consumption.

Alternative explanations for growing public expenditure are visible in several national documents. Poland explained the high deficit in 2011 by its peak in public investment supporting growth, which was at that time in line with the 2009 European Economic Recovery Plan. Moreover, it pointed at expenses related to the absorption of EU funds, which are mostly cofinanced, and spending on infrastructure and the organisation of the 2012 European Football Championship. Complaints also related to the use of outdated information. For instance, Poland reacted to the Commission's forecast of an above-target deficit in 2015 by arguing that these projections did not take into account recently announced consolidation measures. In 2014 also France complained that the Commission's deficit predictions did not take into account its newly announced savings. In fact, 2015 forecasts were based on a no policy change assumption. It did not incorporate a new reduction of central government expenditure, the lowering of the national healthcare expenditure growth target, the delay in the increase of social benefits, and the impact of the Responsibility and Solidarity Pact. France concluded that differences in calculation methods could have great consequences for judgments about meeting EU targets. Moreover, France pointed out that the Commission's predictions sometimes change rather quickly, turning endorsed draft budgets into new worries about deficits. This is a similar issue raised by Poland in the Subsection 11.5.1. France recalled that the Commission endorsed a draft budget in November 2013, but, as soon as the winter 2014 forecast showed a deviation from the targets, the Commission changed their opinion and wanted France to take extra measures. Such deviations in forecasts and actual spending paces also have major consequences for the assessment of effective action in accordance with the Commission's methodology. 


\subsubsection{Legitimacy and Democracy}

The disputes on what sound socioeconomic policies entail and how to measure and predict reform effects show that the effectiveness of prescribed reforms is challenged frequently. The word 'legitimacy' as such is not often mentioned, however. The four countries often write down that they agree with the EU-level aims and instruments. Only a few times legitimacy and democracy is raised. For example, in its stability programme 2014 France argued that the Commission's opinions following the budgetary surveillance of the Two-Pack of are not legally binding, even though France acknowledged that a failure to comply could lead to an acceleration of the EDP. In its 2014 NRP Germany called to improve democratic legitimacy by involving citizens and national parliaments into decision-making. A more pronounced viewpoint is included in the opinion of the French stakeholders, which was annexed to the 2015 NRP. It pleaded to give full meaning to the notion of solidarity so as to re-legitimise the European project in the eyes of citizens. The stakeholders noticed that citizens feel that their society changes and combines the market economy less and less with social protection. Therefore, the social dimension should become a guiding principle of all European policies. Correlations between aspects of democracy and alternative policy implementation may be viewed in Germany and France, however. For instance, the rollback of the French pension reforms coincided with the instalment of a newly elected government. Also the German pension reform, improving the pensions of people with a reduced earning capacity, was introduced by a newly installed government. Reforms going against a CSR or diverting from main EU-level goals, could thus stem from the demands of the electorate.

\subsubsection{National Governments Cannot Influence Everything}

All four countries partly explain their inability to reach fiscal goal via reforms, by referring to the overall $\mathrm{EU}$ economic slowdown. If all EU countries face economic difficulties, taking austerity measures only will not lead to economic growth. The four countries also argued that they cannot influence the economic state of other countries. In 2014 France, for instance, argued that its reform effects were limited due to the general economic slack in the EU. Spain argued that an important economic burden was the international financial crisis as well as the adjustment in its housing sector, the increasing unemployment rate and deteriorating public finances. Some of these dossiers fall outside government control. In addition, the increased interest rate was problematic, causing Spain to consolidate more speedily. Also Poland gave 
two pronounced reasons for its economic slowdown, some years after the start of the crisis: the economic downturn in Poland's main export markets and a rather restrictive macroeconomic policy resulting from EU recommendations. Germany even referred to the weather to explain the lower-thanexpected growth in the winter of 2012/13.

Of the four countries in this study, Spain's views seem to conflict least with the Commission's analyses. It implemented major reforms which were largely along the lines of the Commission's proposals. ${ }^{29}$ However, Spain's confidence to generate fast results decreased over time. The 2011 national reports were still fairly optimistic. Spain was committed to present a programme to exit from the crisis, including fiscal consolidation as well as structural reforms. The country called its fiscal efforts 'very ambitious', and the Commission agreed with this viewpoint. In 2011, Spain based fiscal consolidation measures mainly on nonfinancial expenditure adjustments, while prioritising sustainable growth as much as possible, improving the efficiency of expenditure and restructuring of the public sector. In spite of these efforts the imbalances remained significant. After 2011, the economic and financial situation worsened. A new strategy included a major transformation in 2012, encompassing among others labour-market reforms and reforms in collective bargaining. ${ }^{3 \circ}$ Spain tried to build confidence based on past performance: its proven ability to overcome difficult situations by committing to economic stability and structural reforms. However, Spain was also aware that financial imbalances could not be corrected overnight. Instead, the adjustment pathway would be gradual and steady. Spain assured that it would strive for the largest adjustment of budgetary imbalance in the shortest period of time, but also asked for time and trust.

\subsection{CONCLUSION}

The analysis supports that the European Semester is not a static but an evolving governance system. It adapts its goals to new challenges. The evolving nature of the Semester is relevant to support the ESM. It allows new goals to be included, for instance responding to youth unemployment challenges. Moreover, as was the case in pre-crisis EU social governance, the Semester gives tailor-made

29 M.L. Rodriguez, 'Labour Rights in Crisis in the Eurozone: the Spanish Case' (2014) 1 European Journal of Social Law 128.

$3^{\circ}$ A range of scholars agrees with this classification of reforms being radical, C. Barnard, 'EU Employment Law and the European Social Model: The Past, the Present and the Future' (2014) 67 Current Legal Problems 1; López and Canalda Criado, n. 1 in this chapter; Rodriguez, n. 29 in this chapter; and B. Suarez Corujo, 'Crisis and Labour Market in Spain' (2014) 5 European Labour Law Journal 43. 
policy advices to countries. It means that the Semester does not have a uniform effect on all Member States, also not in social policy domains. The recommendations are contextualised to a large degree and at times give support for prioritising social goals. The analysis also shows that Member States have room to develop alternative socioeconomic policies, even if these go against the EU's recommendations. This is especially the case for countries that are in preventative stages of coordination. However, examples demonstrate that even in corrective arms of coordination, countries may discard EU-level policy advices. Also EU recommendations that support social goals have not always been implemented. It is also important that, within the European Semester, countries bring alternative views into the debate, communicating reform philosophies or questioning the Commission's calculation methods and forecasts. Such arguments can be highly supportive of a social agenda. Member States for instance call to combine consolidation with investment, to spend money on poverty reduction, or to take long-term goals into account. Member States can base these arguments on 'evidence': their experiences with reform effects or their citizens' preferences.

The chapter thus indicates that the throughput stage of the European Semester is relevant in order to understand how new EU socioeconomic coordination offers support to social goals. At least some of the characteristics of the Open Method of Coordination still apply to the European Semester. There is discussion and debate, meaning also that the basic ingredients for mutual learning are still present. However, these characteristics are neither really explicated, nor openly valued for their contribution to effective policymaking. Recent EU policy documents continue to be rather vague on these aspects. They seem to attempt to unite better compliance with valuing diversity among Member States. This means that the Semester remains quite complex, making verdicts about Member States that seem rather surprising given the rules and regulations. It continues to give the throughput phase an important role in determining the outcome the decision-making process, yet does nothing to make this throughput stage more transparent. More insight is needed in how the different economic and social coordination mechanisms relate to each other and how the value of social and economic goals are weighed against each other. Also, more insight is needed in which stakeholders make decisions at what moments in time. Such insights would give other relevant stakeholders, such as the social partners or national parliaments, a better view on when to move into the debate to support social goals. ${ }^{31}$ Also,

31 M. Ferrera, 'Social Europe and its Components in the Midst of the Crisis: A Conclusion' (2014) 37 West European Politics 825. 
better information about how social and economic goals are prioritised might give national-level actors more arguments to defend national choices that support social goals.

The replies of Member States in their national reports show that they already give some reasons for a stronger social perspective. At times they use the Commission's own social goals to support national choices. Such active communication from the national to the EU level may prove to be a valuable input to advance the entire socioeconomic coordination process. In other words, national arguments might trigger learning effects within EU institutions as well. The Commission is already aware of the complex reality of socioeconomic policies and demonstrates this in its Country reports. These explore social and economic policies in a broad and integrated manner. Such rich evaluations could serve as a more justified basis to make a final verdict about a country. The latitude of Member States, bringing in new arguments, but also prioritising alternative policies, can likewise be viewed as a strength of the European Semester. It not only gives Member States space to follow their own reform logic, but also to search for better solutions based on social, economic, and political considerations. If exchanges between the EU and the Member States prove to become positive learning moments for all, then the openness and adaptability of the European Semester becomes an asset. 